\title{
The Influence of Indian Philosophy on French Romanticism
}

Swagata Bhattacharya

\begin{abstract}
France's connection to India dates back to the seventeenth century when the French came to establish trading relations with India and neighboring countries. Even in the heydays of Enlightenment, France, the champion and cradle of Reason and Rationality in Europe, was looking for an alternative and philosophers like Rousseau, Diderot and Voltaire looked towards India as a source of inspiration. That tradition was continued by the French Romantics who were even more influenced and inspired by Indian philosophy and wanted to change the course of French literature with the help of it. This paper aims to explore literary transactions between India and France culminating in the movement called Romanticism in French literature. The paper shall trace the trajectory of how Indian philosophy and thought traveled to Europe in the form of texts and influenced the works of the French from Voltaire in the eighteenth century to Jules Bois in the twentieth. The central argument of this diachronic study, based on the theory of influence, is to prove how significant the role of India and her literary/religious texts have been in the context of the Romantic Movement in French literature in the nineteenth century.
\end{abstract}

Keywords

Influence, Philosophy, Rationalism, Romanticism, Orientalism 



\title{
The Influence of Indian Philosophy on French Romanticism
}

\author{
Swagata Bhattacharya
}

\section{Introduction}

For students of Comparative Literature, 'influence' is a specific term related to the discipline. Coined from Middle Latin 'influentia' (from the verb 'fluere' meaning 'to flow'), influence is used in English since 1658 to denote a link or connection between two objects. According to Merriam-Webster, the word influence means 'the act or power of producing an effect without apparent exertion of force or direct exercise of command'. Scholars such as Owen Aldridge argue that influence can be defined as something existing in the work of a particular author as a result of his familiarity with the works of another author. That is to say, to be considered as an influence, there must be something in the work of an author which could never have existed had he not read the works of the other author (1963 144). This 'something' may be in terms of theme, form or style. Overall, influence is never confined to individual details and it cannot be measured quantitatively. Influence never reveals itself in a single, concrete manner but gets organically involved. Hence, influence must be sought in several different manifestations.

In this study on the influence of Indian philosophy on French Romanticism, these different manifestations have been revealed across time i.e. diachronically from the Enlightenment period on words. Also, in this article, the term 'philosophy', has not been used in the sense of a particular discipline or knowledge system as it is conceptualized in the West. Rather, it has been used as a rough translation of the Sanskrit word 'Darshan', the closest English term for which should be 'worldview'. Hence, the philosophy being referred to here is not nearly aesthetics or ethics or metaphysics - it is a comprehensive and consolidated worldview of India which represents the Orient, the anti-thesis to the Occident.

\section{India's Influence on France: the Initial Years}

India's French connection dates back to the seventeenth century when the French established their East India Company in 1664.Les établissements français dans 1'Inde (French settlement in India) included Pondicherry, Karikal, and Yanaon on the Coromandel Coast, Mahe on the Malabar Coast and Chandernagor in Bengal. Based on 
these territories, France began to give tough competition to Great Britain in the 17th century in the realm of both trade and control of political affairs in India. The tussle continued for almost 100 years finally culminating in the Seven Years War in Europe (1756-1763). The vanquished French eventually agreed to sign the Treaty of Paris (1763) which almost ousted them from India. Forced to surrender their territories acquired in India, the French lost their political power and successful business ventures in the subcontinent. Yet, they managed to retain two posts in the country-Chandernagor in the East and Pondicherry in the South. These two places, said to be the strongest bases of French power in India, hosted the origin of the French Oriental Study which began roughly around the 18th century.

Thus, France's connaissance with India began through trade but it did not remain confined only to trading relations. There was an urge to 'know' India and this urge, too, like most other things, was marked by a pronounced rivalry with the British. As a result, by the mid-18th century, France engaged herself in Indic Studies. French Jesuit missionaries, who had arrived along with the French merchants, were interested in ancient Indian manuscripts written in Sanskrit and started collecting them. By 1735, the Bibliothèque du Roi in Paris had a collection of Sanskrit manuscripts arriving from India and in 1739, the first catalog of these manuscripts was published. There were approximately 200 manuscripts collected by Jean François Pons, one of the missionaries, who traveled to Bengal in the East and collected different texts of the Vedas, Puranas and Sastras. Pons' collection contained scripts in the Bengali language too, along with Sanskrit. Besides, Vopadeva's Mugdhabodha, Amarkosha, etc were all available to him. Based on these Sanskrit and Bengali texts, Pons prepared a dictionary of Sanskrit words and explanations of the texts in Latin (Filliozat 31-2).

Meanwhile, the British were advancing well in their Oriental Studies by centering in and around Bengal. Sir William Jones established the Asiatic Society of Bengal in Calcutta in 1784 and published the English translation of The Bhagavad Gita, considered to be the most sacred of all Indian texts. The French did not lag behind, Charles Wilkins' English translation was re-translated into French by Abbé Parraud in 1787. Louis Matthieu Langlès, the then curator of Oriental Manuscripts at the Bibliothèque nationale at Paris took it as a policy to document in the Magasin Encylopédique all major works of Indian philosophy and/or literature that were translated into English and published by the Asiatic Society of Bengal (Tathagatananda 47).

Triggered by her obsession to compete with Great Britain, France played a crucial role in disseminating Oriental philosophy and knowledge to the rest of Europe. By the end of the eighteenth century, Paris had transformed itself into a hub of Oriental learning and German scholars frequently visited Parisian universities and libraries to collect study materials (Tathagatananda 47). Most notable among them was August Wilhelm Schlegel. Franz Bopp, who was reportedly noted to have studied Sanskrit in France up to 1816, was instrumental, along with Schlegel, to eventually transfer the Centre of Oriental Studies in Europe from Paris to the universities of Berlin and Bonn in Germany (Tathagatananda 48-9). 
However, that hardly mitigates France's significance as far as Indic Studies was concerned in the eighteenth and nineteenth centuries. < langue en vogue> in the academic circle of France was Sanskrit and the process behind it was undoubtedly initiated by the French theologian Abraham Hyacinth Anquetil- Duperron (1731-1805). Back in 1754, Duperron had discovered four leaves in a facsimile of the Zend Avesta, the religious text of the Persians, at the bibliothequè du Roy in Paris. It was handed over to him by Andre le RouexDeshauteraye, Professor at Royale College, Paris. Till then the text was undeciphered and Deshauteraye wanted Duperron to decipher it. He also informed him that the original text was with James Frazer (1713-1754) who was with the British Army and had returned from India with several Persian and Sanskrit manuscripts. Armed with this information, Duperron traveled to Britain to obtain the manuscripts and was thoroughly disappointed with the attitude of the British. Realizing that they had no intention of deciphering these ancient texts from India, he decided to travel to India on his own. The paucity of funds forced him to enroll in the French Army and was asked to join the regiment stationed at Pondicherry. In 1755, Duperron landed in Pondicherry and thereby began an eventful episode in his life under the Jesuit Missionaries. He managed to take lessons in Persian first and later in Sanskrit. In 1762, Duperron returned to Paris with several manuscripts and engaged himself in translating them. The result was the publication of Avesta, Ouvrage de Zoroastre in 1771. As soon as Avesta was published, a heated argument broke out in the Continent between the French and the British. William Jones was thoroughly annoyed with Duperron's criticism of the British attitude towards ancient Oriental texts and dismissed the manuscripts collected by Duperron as 'insignificant' (Dormesteter xii-xiv). However, Duperron was credited for translating the first religious text from the Orient to be published in France.

Meanwhile, a Frenchman called Louis- Laurent Federbe de Maudave returned from India with a text called Ezour-Vedam, a 'supposed' translated version of the Yajur $V e d a$ in 1760. He handed over the text to Voltaire (1694-1778) who officially presented the book to the Bibliothèque du Roi in 1761 and was himself so fascinated with India on reading the book that he wrote Fragments historiques sur l'Inde(Historical Fragments on India)in 1772, in which he declared that everything has come down to Europe from the banks of the Ganges (Voltaire 386). The EzourVedam, however, was not an authentic translation of the Veda. It was fabricated by the French Jesuits settled in Pondicherry with the intention to denounce Indian idolatry and thereby indirectly establishing the superiority of Christianity, a pet project that was to continue till the 1900 Paris Congress of the History of Religions in which Swami Vivekananda was invited to participate. But back in 1772, Voltaire looked upon this as an opportunity to express his disbelief on the Christian worldview. He volunteered to offer an alternative discourse on religion and spirituality to Europe by turning its attention towards India. By then, his philosophical conte Candide (1759) and his essay < Bien, tout est bien> (published in 1764 in Dictionnairephilosophique) had demonstrated his frustration with Christianity. He wrote:

This system of all is well represented, the author of all nature as a potent, malicious king, who never worries if his designs mean death for four or five 
thousand of his subjects, and poverty and tears for the rest, as long as they gratify him (Adams 86).

In his Essai sur les moeurs et l'esprit des nations, Voltaire expressed optimism about Indian philosophy and wisdom because he believed that India was the most ancient civilization and she, therefore, must have had the most ancient form of religion (1990, 237). Even Denis Diderot was in favor of offering an alternative to the Biblical worldview and hence concentrated on the wisdom of ancient Indian religion since that worshipped Nature in its various forms. Thus, his Encyclopédie, among many other things, included articles on the Indian religion. Published in thirty-five volumes from 1751-1772, Encyclopédie was the landmark publication of the era. In France, the eighteenth century was < le siècle du lumière> (the century of light) and French Enlightenment was at its height between 1715 (the year marking the death of Louis XIV) and 1789 (The year of the French Revolution).René Descartes (1596-1650) and his proposition $-<<$ Je penseDonc je suis $>$ (I think; therefore I am) had paved the way for philosophers such as Diderot, Rousseau and Montesquieu. Butas les philosophes set up scientific academies, printed books and issued pamphlets on renouncing absolute belief and faith in divinity, side by side they were looking for an alternative to dependence on absolute Reason.

This alternative was provided to them by Nature. Jean-Jacques Rousseau and Diderot upheld Nature over both God and Rationality and that got manifested in French Literature which changed its course during this period. Rousseau's La Nouvelle Héloise (1761) "talked about rights of imagination, emotion and individualism". Rousseau (17121778) headed the reactionary movement against reason and rationality which was dominating Europe and particularly France at that point of time. Jacques-Henri SaintPierre's Etude de la Nature (1784) and Paul et Virginie (1788) brought back the themes of nature and innocence and ushered in the Romantic Movement in French Literature, which was highly indebted to Indian philosophy. Charles Augustine Saint-Beuve had remarked that Chateaubriand is the father of Romanticism, Jean-Jacques the grandfather, Bernardin the uncle and another uncle arrived from India particularly for this purpose (Saint-Beuve 122). The reason behind such a remark was surely the works of Chateaubriand. Though Mmede Stael's De l'Allemagne (1813) is generally considered to have ushered in the new movement called Romanticism in French literature, FrançoisRené-Auguste de Chateaubriand (1768-1848), <<le père du romanticism >>had already brought in < le vague des passions > (the wave of passions) and < le mal du siècle > (the evil of the century) - the two main themes which were to dominate French Romanticism till 1835 - through his works Les Natchez (1793-99), Atala (1801), René (1802) and Génie du Christianisme (1802).Lamartine later commented on Chateaubriand, Lamartine in his Destinées de la Poésie(1834) that Chateaubriand possessed - <<imagination homérique...semblable à ces belles colonnes de PalmyreRestèes...(sur les tentesnoires et dèchirèes des Arabes, admirer et pleurer le monument qui n'est pas plus! >> (Homeric imagination...resembling the beautiful columns of Palmyre... resting on the dark and torn tents of the Arabs to admire and cry for the monument that no longer exists) [Tilley 3]. 
Such a comment reflects the French psyche - to the French, particularly the Romantics, Chateaubriand's works echoed the romance of the distant Orient, a land of mysticism, the path to which lay through India. Very interestingly, India has repeatedly been referred to as <<les Indes >> stressing the significance of the plurality that it is not just one country, but a conglomeration of races, languages and cultures representing the Orient, the significant 'other' of the Occident.

The significance of the Orient grew by leaps and bounds with the arrival of the Upanisadsin the continent. Again, it was Duperron who translated them into French after being presented with a Persian translation of the Upanisadsin 1775 by his friend M. Jean Baptiste Gentil. A French resident at the court of ShujaUddaulah in Faizabad, Gentil had come across the translation of the fifty Upanisads by Dara Shikoh, the rightful heir to Mughal throne killed by his younger brother Aurangzeb in 1659. His translation completed in 1657 and left unnoticed for the next hundred years was translated into French by François Bernier, who was the resident French doctor in Aurangzeb's court from 1658-1668. In 1786, Récherches sur l'Inde published translations of four Upanisads by Bernier. Later in 1796, Duperron completed the Latin translation and published it in two volumes in 1801 and 1802 under the title Oupnek'hat. The publication of Oupnek'hat brought a new direction to the study of the Orient in France.

\section{India's Influence on the Romantics:}

It was in 1796 that Chateaubriand had published his Essai sur les Revolutions. One of the chapters of this book was titled <<Kreeshna fragment du poème Mahabharata, tiré du Sanskrita Sacontala >> (Krishna fragment from the poem Mahabharata, extracted from the Sanskrit Sakuntala) (Tathagatananda 83). This title, however, is somewhat confusing for us. 'Sacontala' or 'Sakuntala' is the popular name by which the Indian poet Kalidasa (c $1^{\text {st }}-4^{\text {th }}$ century CE)'s Sanskrit play Abhijnanasakuntalam is known. We all know that Kalidasa took the plot from the Mahabharata which contained an episode on Sakuntala and king Dushyanta. Chateaubriand's knowledge about Sakuntala must have been derived on reading the Mahabharata of which Sakuntala was a part and not vice-versa. $<<$ Mahabharata tiré du Sacontala $>$ would indicate that Mahabharata is an extract from Sakuntala. Thus, it is uncertain whether this is another case of 'lost in translation' or inadequate knowledge about texts from the Orient. Or, it may even be the fact that Sakuntala influenced and won over the hearts of the European connoisseur in the eighteenth century to such an extent that even the two Indian epics, The Ramayana and The Mahabharata, were considered insignificant in the West. William Jones translated Sakuntala into English and published it in 1789. As soon as the play was available in Europe, its German translation appeared in 1791. From 1788 onwards, the Asiatic Society of Bengal published Asiatic Researches: Transactions of the Society which were all being translated into French. In 1800, the journal Decade philosophique published extracts from Jones' translation of Sakuntala in French (Tathagatananda 204). Influenced by both William Jones and Georg 
Forster's English and German versions respectively, the first French translation of Sakuntalawas published in 1803. The translator was Brugiere de Sorsum who was involved in French administrative service in Westphalia, Germany. However, it is evident that Chateaubriand was aware of Sakuntala and may perhaps have read the play in English translation before 1796. His exile in England from 1793 onwards did present before him the opportunity to be acquainted with the play. The Oriental Renaissance (1984) mentions that Chateaubriand had listed Sakuntala under Sanskrit poetry in his Genie du Christianisme(Schwab 83). An updated version of the Essais was published in 1826 in which Chateaubriand included an overall summary of the progress of Sanskrit studies in France from 1796 to 1826, proving his interest in the language and culture of India (Tathagatananda 203-5).

This attraction towards Sakuntala and Oriental philosophy/wisdom continued throughout the nineteenth century in France. Lt Alexander Hamilton, employed by the British, collated Sanskrit manuscripts at the National Library in Paris and gave Sanskrit lessons to Constantine Volney, Louis Matthieu Langles, Claude Fauriel and Friedrich von Schlegel. In Le Ministere de l'homme-esprit (1803) Claude de Saint-Martin remarked that literature from India was offering numerous treasures to them (203). Schlegel's knowledge of Sanskrit enabled him to translate excerpts from The Ramayana and The Mahabharata as well as The Laws of Manu into German between 1803 and 1804. In 1804, he taught a course privately on World Literature in Paris, which included these Sanskrit texts. The availability of the devnagari font as typeface prompted German scholars to throng in Paris. Schlegel stayed back in Paris as late as 1825 to obtain the devnagari font for his editions of the Hitopadesa and the Bhagavad Gita, after which the center of Orientalist study in Europe gradually shifted from France to Germany (Tathagatananda 204-5).

The year 1821 saw the establishment of the Société asiatique des Paris and Paris became the first European city to officially provide teaching of the Sanskrit language. In the first general meeting of the Société held on April 1, 1822, "the need for a better instrument than the existing Indological journals" was announced (Tathagatananda204). Thus appeared the JournalAsiatique in 1823, which chose to concentrate on studies related to the culture of Asia and not solely to the interests of the East India Company. This was a major point of departure from where India was no longer being looked upon as the 'exotic other' but as the viable alternative from whom Europe needed to take lessons.

In 1830, the most notable among the French Indologists, Antoine- Leonard de Chezy (1774-1832) translated Sakuntala from Bengali to French, using Goethe's famous poem on the play as an epigraph. ${ }^{1}$ Goethe had read Forster's German translation of the

\footnotetext{
${ }^{1}$ Wilst du die Bluthe des fruchen, die Fruchte des spaterenJahes,

Wilst du, was reizt und entzuckt, Wilst du was sattigt und nahrt,

Wilst du den Himmel, die Erde, mit EinemNamenbegreifen
} 
play and was so fascinated that he again read it in English and composed a poem in its praise. His small poem opened the floodgates of scholarly interest of Europe who woke up to the fact that the key to Indian philosophy and literature was perhaps embedded more in this play than in scores of religious or so-called sacred texts. Chezy's translation was considered to be more accurate and was much more appreciated than Sorsum's translation. In the September 1832 edition of the Revue de Paris, Chezy, along with Jean-Pierre Guillaume Pauthier, published translations of excerpts from The Mahabarata which again included the episode of 'Sakuntala' apart from 'Nala-Damayanti' and the episode where Draupadi was publicly humiliated and molested at the royal court. It was titled 'The Abduction of Draupadi', another case of misinterpretation of texts from the 'other' culture. The episode of 'Sitaharan' in the Ramayana has been translated into English as 'The Abduction of Sita'. The West tried to follow a similar pattern in the case of The Mahabharata and titled the episode of 'Vastraharan' as 'The Abduction of Draupadi'. These episodes were re-published in Journal Asiatique by Théodore Pavie between 1839 and 1841 .

A French translation of the Bhagavad Gita was published in 1832 by Jean-Denis Lanjuinais who translated it directly from Sanskrit. The first volume of the Ramayana appeared in French translation in 1853, translated by Valentine Parisot. Hippolyte Fauche (1797-1869) was so influenced by the Ramayana that he embarked on a study of a number of ancient Indian texts and translated Kalidasa's plays and published them in two volumes in 1859 and 1860. The French poet Joseph Méry (1798-1865), too, was mesmerized by the works of Kalidasa and Bhavabhuti and went on to establish himself as a Kalidasa's scholar in the nineteenth century France.

Sakuntala's influence did not remain confined to Chateaubriand or Indologists like Chezy. Louis Renou notes that the three principal poets of the Romantic period Alphonse de Lamartine (1790-1869), Alfred-Victor de Vigny (1797-1863) and Victor Hugo (1802-1885), too, were greatly influenced by the play. Lamartine considered it a masterpiece of both epic and dramatic poetry, combining in one work the essence of the pastoral charm of the Bible, of the pathos of Aeschylus and tenderness of Racine (Lamartine ix). Again, in his Opinions sur dieu published centuries later in 1984, Lamartine is quoted to have said - "It is the ocean, we are but its clouds [...] The key to everything is in India” (ix). Even Vigny's Journal d'un poète mentions his praise and

Nenn'ich, Sakoontala, Dich, und se ist Allies gesagt (http://ancientgems.blogspot.com)

[Wouldst thou the young year's blossoms and the fruits of its decline,

And all by which the soul is charmed, enraptured, feasted, fed?

Wouldst thou the earth and heaven itself in one name combine?

I name thee, O 'Sakoontala'! and all at once is said]

[Translation by E.B. Eastwick published in 1853] 
appreciation for Sakuntala.

The most celebrated of the French Romatics, Victor Hugo, was never in awe of India. Though he began his life as a devout Catholic, he later considered himself to be a rational deist. However, his 'Suprématie' demonstrates his engagement with Indic Studies where he based his poem on an episode from the KenaUpanisad in which 'Agni' (Fire) and 'Vayu' (Wind) tussle with each other to conquer a blade of grass. It was published in his Legend of the Ages (1870). The profound philosophy of the Upanisads gets manifested through these lines:

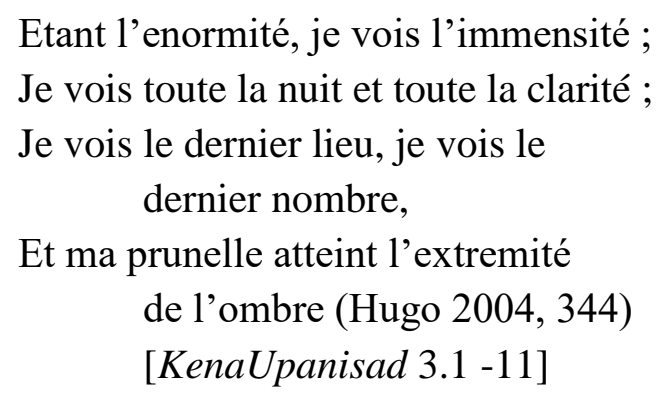

(Being enormous, I see immensity;/I see the entire darkness and the entire clarity;/I see the last place, I see the last number,/And my pupils await the extremity of the shadow) [Hugo 344]

In his book Littératurefrançaise et pensée hindoue des origins à 1950 (1974), Jean Biès mentions that Hugo believed that the Asian civilization was not devoid of higher men and profound thoughts as Europe had wished to believe so far. Hugo's contemporary Edgar Quinet prophesied an 'Oriental Renaissance' for Europe - “... an antiquity more profound, more philosophical, and more poetical than that of Greece and Rome was emerging from the depths of Asia" (Schwab 11). Jules Michelet's La Bible de l'humanité (1864) spoke at length of the peace and softness of Asia. He was so deeply moved by the Ramayana that he referred to the epic as, $<<$ la bible de la générosité ... la mer du lait" $>>$ (Michelet 109-10).

In the $20^{\text {th }}$ century, Jules Bois, tried to bring in a new kind of Romanticism with his Visions de l'Inde. Acquainted with Swami Vivekananda during his last trip to Paris in 1900, Bois visited India in 1902 after receiving the news of Swamiji's demise. His Visions de l'Inde (1903) projects India as a spiritual gate-away from the artificial civilization of Europe. Bois' work, though, has never been accorded much significance in the canon of French literature. Visions de l'Inde has been dismissed as an exaggerated and over-romanticized text banking on the common notions of the West that India is a land of magic and supernatural.

\section{Conclusion}

Like all other literary movements across time and space, French Romanticism did 
not begin or end on a definite date, neither was it triggered by any one particular incident. It was a result of several influences, one of them being the philosophy arriving from India. As discussed in the beginning of this article, influence does not reveal itself in a single, concrete manner, it needs to be sought in several different manifestations. The works of the French Romantics such as Chateaubriand, Hugo and Lamartine have manifested in their own ways that they have been influenced by India and her worldview. Previously their works have not been analyzed from this point of view and the Indian connection have been considered too insignificant to ponder on the overall impact India might have had on French literature. Consequently, there has not been much research on this area. However, this article shows that Indian thoughts did travel to France via translations of literary and religious texts written mostly in Sanskrit and provided a much-needed alternative to France which wanted to move beyond Christianity and embrace spirituality, the fountainhead of which was India.

\section{Works Cited}

Adams, Robert M. Ed. Candide. New York, Norton, 1991.

Aldridge, Owen. Comparative Literature Studies Advanced Issue 1963.

Bois, Jules. Visions de l'Inde. Paris, Societed' Editions, 1903.

Danino, Michel. "India's Impact on French Thought and Literature" www.pragyata.com

Dormesteter, James. Zend Avesta Part I. Oxford, Clarendon, 1880.

Filliozat, Pierre Sylvain. "Sanskrit Studies in France" www.sanskrit.nic.in

Hugo, Victor. Selected Poems of Victor Hugo: A Bi-lingual Edition. Chicago, U of Chicago, 2004.

Lamartine, Alphonso de. Opinions sur Dieu, le bonheur et l'eternited'apres les livres sscres de l'inde Paris, Sand, 1984.

Michlet, Jules. La Bible de l'humanite vol.5 Paris, Larousse, 1930. Saint-Beauve, Charles Augustine. Portraits Litteraires vol. ii Paris, Garnier-Frerest, 1836.

Schwab, Raymond. The Oriental Renaissance: Europe's Rediscovery of India and the East 1680-1880. New York, Columbia University Press, 1984.

Stewart, H. F. and A.A. Tilley. The Romantic Movement in French Literature.

Cambridge, Cambridge University Press, 1917.

Tathagatananda, Swami. Light from the Orient - Essays on the Impact of India's Sacred Literature in the West. Kolkata, Advaita Ashrama, 2005.

Voltaire. Essai sur les moeurs et l'esprit des nations. Paris, Classiques Garnier, 1990. Oeuvres completes vol.29 Paris, Hachette, 1893. 


\section{The Author}

\section{Dr. Swagata Bhattacharya,}

Post-Doctoral Fellow,

Department of Comparative Literature,

Jadavpur University

Kolkata-700032, India

Email: swagatarchithi@gmail.com

\section{The Article}

Date Sent: 08/03/2021

Date Revised: 12/05/2021

Date Accepted: 15/06/2021 